\title{
COLECTÁNEA: UNA NUEVA SECCIÓN DE ACTA BIOETHICA
}

El trabajo editorial en el ámbito académico tiene dimensiones insospechadas. Obliga a renuncias y restricciones con el fin de resguardar la retórica aceptada en las disciplinas académicas y la forma canónica de presentar los productos de la investigación y la erudición. Nadie, hoy día, publicaría sus resultados empíricos en forma de verso y si un autor no respeta las normas editoriales de las publicaciones periódicas verá rechazados sus manuscritos. A ello se añade la exigencia propia del campo disciplinario específico, las citas honorables y necesarias en un campo del saber, el trabajo concienzudo en las notas al pie de página, cuando son necesarias y aceptadas, y la inserción adecuada en una tradición de preguntas. Tales son, entre otros, desafíos para el editor científico, que tiene un imperativo técnico, moral y social pues vela, como guardián, por la calidad de lo publicado y la elegancia del producto final.

Con Álvaro Quezada, nuestro diligente editor en Acta Bioethica, a veces hemos debido rechazar textos que en el aún difuso campo de la bioética no cumplen requisitos formales en cuanto a estilo, longitud o forma de citar. En la región latinoamericana faltan unánimes estándares para juzgar calidad. Algunas personas creen que bastan buenas intenciones o defender cosas como los derechos humanos para que los productos sean intelectualmente valiosos. Nadie discute la necesidad de ocuparse de ciertos temas, o aún la bondad y bienaventuranza de los adalides de grupos políticos que dicen defender a personas y causas. Pero es bueno llamar a las cosas por su nombre. Y cuando alguien quiere publicar un trabajo de relevancia académica, lo menos que se le puede pedir es que tenga justamente eso: relevancia académica.

Ciertamente, es una noción compleja. Sólo los pares en la disciplina o las autoridades aceptadas pueden permitirse juicios sobre calidad, pertinencia o relevancia. Y si en algo pueden pecar los editores, como ya lo reconocía Jacques Le Rond D'Alembert, aquel insigne gestor de la Gran Enciclopedia de 1751, es en dejar sin público lo bueno o en publicar lo malo. De estos yerros, qué duda cabe, el segundo es con mucho el más execrable. Del primero, quienes hemos hecho trabajo editorial hemos sido alguna vez culpables. De modo que no entraremos en disquisiciones mayores y diremos que nuestra conciencia está tranquila en cuanto a pecados de ambos tipos en Acta Bioethica.

Con el tiempo hemos percibido la necesidad de que vean la luz materiales que no vienen en el código de una revista "indexada" y examinada por pares, como la nuestra. Ponencias nunca completadas, resúmenes de conferencias, notas preliminares, comunicaciones breves, colecciones de textos misceláneos, en un área aún no consolidada del todo, deben encontrar lectores y merecen difusión. Por ello hemos creado esta nueva sección, en la que aceptaremos envíos constituidos por resúmenes de seminarios, simposios y reuniones, bosquejos preliminares que, no siendo formalmente manuscritos publicables, merecen difusión. Ciertamente, serán examinados por evaluadores externos y exigiremos legibilidad y solvencia. Pero no tendrán el carácter de publicaciones completas. Y podrán ser citados como textos de Acta Bioethica.

En la lógica de un editor científico, una sección como esta carece de sentido. Incrementa el número de páginas pero no la probabilidad de las citaciones. Por ende, no contribuye al impacto. Es espacio tan muerto como el de las recensiones y comentarios bibliográficos, pues los sistemas de referencia son ciegos frente a este tipo de materiales. Por lo menos, en la tradición que aceptamos y con el rigor que pretendemos. Pero, al igual que las "cartas" y las "comunicaciones breves", se han convertido en una necesidad para nuestra feble comunidad bioética latinoamericana, tan amenazada por la irresponsabilidad intelectual, la demagogia turbia del populismo fácil y la falta de seriedad para la controversia. Espero que esta sección no se convierta en "cajón de sastre" u "olla podrida" de productos impublicables. 
Habíamos decidido denominar "analectas" a esta sección. Analectas es bella locución. Refiere a "cosas recogidas" y su plural es muy sugerente porque se condensa en la voz "florilegio". Después de sopesar ideas, llegué a la conclusión, compartida por nuestros expertos, de que tal vez la denominación sugeriría -erróneamente- la noción de "cosas escogidas", selectísimos y escogidísimos productos. Lo cual, como se ha explicado, no es el caso ni está en la intención. No quiero insinuar que se trata de lo opuesto, pero sí indicar que el nombre de "colectánea” (en el sentido de “colección”) es más neutro, más prudente, más modesto. Más sobrio, en suma, que sobriedad suele faltarnos en empresas como ésta de la bioética, tan susceptible en nuestras tierras de convertirse en trampolín de ambiciones demagógicas, magma de fanatismos, sustancia de guruísmos. Y si algo queremos reconocer como nuestra contribución, cuando se examine esta historia, es que no cedimos a tentaciones y optamos por la sobriedad y la modestia.

No nos hacemos responsables, por principio, de las opiniones que en esta sección se viertan. No representan sentir alguno que nos represente a nosotros. Esta es atalaya y es ventana. Estará abierta a todos los que, teniendo materiales algo informes pero dignos de lectura, decidan confiarlos a nuestra difusión. La que por cierto se ejerce con prudencia y responsabilidad.

Tenemos la esperanza de brindar un espacio no convencional para textos que, de otro modo, quizás no verían la luz pública. Invitamos a nuestra lectoría a usarlo y lo inauguramos con algunos ejemplos de los muchos que nos han sido enviados.

Fernando Lolas Stepke 